\title{
Inflation, Money and Economic Growth in Cameroon
}

\author{
Henri Ngoa Tabi \\ Director of the Center of Research and Studies in Economics and Management \\ Faculty of Economics and Management, University of Yaoundé II, Cameroon \\ E-mail: ngoa_henri@yahoo.fr \\ Henri Atangana Ondoa (Corresponding author) \\ Lecturer in the Faculty of Economics and Management, University of Yaoundé II, Cameroon \\ E-mail: atanganaondoa@yahoo.fr
}

Received: December 29, 2010 Accepted: January 25, 2011 doi:10.5430/ijfr.v2n1p45

\begin{abstract}
For some decades now, anti-inflationary monetary policies have been adopted by the Central bank of the CEMAC zone in view of sustaining economic growth. Despite the low level of inflation recorded, the economic growth of Cameroon remains fragile. The objective of this article is to analyse the relationship between economic growth, inflation and money in circulation using a VAR model for the period 1960-2007. It is shown that increase in money supply increases growth and that growth causes inflation; however, an increase in money supply does not necessarily increase inflation.
\end{abstract}

Keywords: Inflation, Money, Growth and Policy

\section{Introduction}

The view that low inflation is an important requirement for sustained economic growth became widely accepted after the great depression in the 1930s. Thus, low inflation is always considered as an objective of economic policy, it has been shown that volatility reduces economic growth and is therefore worthy of our attention (Klomp and Haan, 2009). Furthermore, it is likely that inflation disproportionately affects poor people, since consumption patterns are much more sensitive to variations in real income at low levels of income. According to Motley (1994) and Taylor (1996) a 1\% increase in inflation reduces productivity by $0.03 \%$ and $0.25 \%$ respectively. And more, it had been shown that inflation deteriorates the performance of financial markets. Thus, all initiatives oriented towards financial development in the presence of inflation cannot boost growth. For example, during the period 1970-1980, the development the financial development in Latin America reduced significantly economic growth because some of the countries in the region were experiencing a high level of inflation (De Gregorior and Guidotti, 1995). More so, inflation creates a doubting atmosphere for decision making at the level of enterprises and reduce efficiency of capital. For this, and contrarily to Tobin (1965), the global volume of capital is reduced during a period of hyperinflation (Mckinnon, 1973; Shaw, 1973); however, the monetary sphere ameliorates overall productivity of factors when the inflation rate is low. But it is not shown that a high level of inflation reduces the overall productivity of factors of production (Ho-Chuan Huang, Shu-Chin Lin, Dong-Hyeon Kim, Chih-Chuan Yeh, 2010). But, in the short run, faster real growth may be associated with more rapid inflation. Often, this is because strong growth is the result of a rise in aggregate demand that causes real output to increase at the same time as it bids up prices. To reduce inflation, the central bank must curb aggregate demand, and this may lower output and employment temporarily. If inflation has a long-run influence on output (in levels or growth rates), it is probably because it affects aggregate supply rather than demand (Motley, 1994).

In Cameroon, the overall objective of the Structural Adjustment Program of the phases I and II was to establish internal and external equilibrium in view of realizing a durable and equitably distributed growth. Thus, the main objectives was (i) to reestablish an equilibrium to major macroeconomic components notably a mean growth rate of $5 \%$ to a low inflation rate of $2 \%$ per year and a stabilization of external accounts with a deficit of the current account lower than $2.5 \%$ of the GDP, (ii) to fight against poverty and (iii) to promote good governance (BAD, 2002; 2007). Although, the objective on inflation seems to be attained since there was a relatively better mastery of prices during the last decade with the rate of inflation around the neighbourhood of $1.9 \%$ in spite of a peak of $5.1 \%$ in 2006 . This peak was due to the evolution of the prices of food products as well as those of transport services due to consecutive increase in petroleum products (MINEP, 2009). Inflation was however estimated at 4.4\% in 2009 against $5.3 \%$ in 2008 . This relatively low 
inflation rate is as a result of the implementation of the Central Bank policy. Indeed, the objective of the monetary policy of the CEMAC zone is to stabilize the common money used within the zone. In the CEMAC zone and in an operational manner, money stability signify that (a)an external coverage rate of money greater than $20 \%$; (b) low inflation which does not divert fundamentally from that of the Euro zone in order to maintain competition. Briefly, the Central Bank upholds clean and solid growth which does not consider important money disequilibrium (Mamalepot, 2004). In spite of the relatively low rate of inflation (less than $4 \%$ per year), the rate of economic growth is fragile in Cameroon. Indeed, during the period of the implementation of the poverty reduction strategy paper (DSRP), i.e. from the years 2003 to 2007, the Gross Domestic Product (GDP) of the Cameroonian economy had a mean real growth rate of $3.32 \%$. This growth rate is below the growth rate observed for the years 2000 to 2002 during which Cameroon was not implementing any formal programme for fighting poverty (MINEP, 2009). This study attempts to examine the effect of inflation and money growth on the rate of economic growth in Cameroon. To do this, the work is organized as follows: section two presents the literature; sections three and four develop respectively the methodology and the results of the study.

\section{Review of Related Literature}

Inflation might affect aggregate supply in several ways. First, inflation may make it more difficult for households and firms to make correct decisions in response to market signals. When most prices are rising, economic agents may find it more difficult to distinguish between changes in relative prices and changes in the overall price level. This difficulty may interfere with the efficient operation of the price system and so slow growth (Howitt, 1990).

Second, inflation imposes various costs that would disappear if average prices were stable. Familiar examples are the menu costs of changing prices and wage rates frequently, the search costs imposed on buyers and sellers when prices change often, and the costs of economizing on holdings of non-interest-bearing money. In addition, Feldstein (1996) has suggested that even relatively low inflation imposes significant deadweight losses on the economy when the tax system is not fully indexed. In addition to these pecuniary costs, inflation also has social costs because it has differing effects on economic agents, with some benefitting and others being harmed. These differential effects add to the uncertainties that agents face, which may be undesirable even for those who turn out to benefit. Moreover, private actions taken to avoid these effects may hurt the overall economy but yield no overall benefits. For example, in an inflationary economy, talented persons may devote their energies to mitigating the effects of inflation rather than to developing products and processes that would raise overall living standards. Unfortunately, these activities often are included in measured GDP, which may make it difficult to identify the negative effects of inflation (Motley, 1994).

Finally, inflation may affect saving and investment decisions, reducing the proportion of GDP devoted to investment and so causing the economy to accumulate less human or physical capital. For example, when inflation is high, it often is more variable, thus harder to forecast. This may make it more difficult to deduce the real returns on investments from available market information and may cause savers and investors to be less willing to make long-term nominal contracts or to invest in long-term projects. The resulting reduced stocks of productive capital may, in turn, imply lower levels of future GDP (Motley, 1994).

These arguments suggest that there are a number of reasons why persistent inflation might tend to reduce the level and/or growth rate of GDP in the long run. A cursory look at the data suggests that they are consistent with these predictions. Using a sample of 58 countries with reasonably high quality data, 6 the raw correlation between average inflation and real per capita GDP growth between 1960 and 1990 is -0.25 , which is significant at the 5 percent probability level. Barro (1991), Cozier and Selody (1992), and Fischer (1993) also conclude that countries with higher rates of inflation tend to have lower rates of real growth in the long run. However, Levine and Renelt (1992) and Levine and Zervos (1993) argue that cross-section regression estimates of the relation between GDP growth and a variety of potential causal variables including the inflation rate tend to be fragile in the sense that the results are sensitive to the precise set of variables included in the equation. Thus, they argue that this research is unusually subject to the dangers of data-mining. This paper tries to deal with this problem by basing the empirical analysis on a well-established theoretical model of economic growth, by making use of the restrictions the model implies, and by avoiding the inclusion of other variables. This approach may provide more precise estimates of relevant parameters and, perhaps more important, guard against the dangers of data-mining emphasized by Levine and his co-authors. This paper concludes that lowering inflation by 5 percentage points (roughly equal to the decline in inflation in the U.S. from the 1970s to the 1980s) would raise average annual real growth by at least 0.1 percentage point and perhaps by as much as 0.5 percentage point. The effect is larger than most estimates of the short-run costs of lowering inflation (Motley, 1994).

In addition, there exist two opposing debates on the causes of inflation. We have the monetarist dominated by the works of Friedman $(1953 ; 1960)$ the pioneer and Saini (1982) and the structuralist dominated by the works of Bruno (1978) and Cordon (1988). While the monetarist attribute inflation to more than proportionate increase in money supply to 
increase in the national product, the structuralist attribute increase in the general price level to non-monetary intrinsic rigidities to the economic system in question.

Thus, for the monetarist, the immediate cost of inflation is an abnormal rapid increase of the quantity of money with respect to the volume of production. Thus, inflation is an excess aggregate demand problem stimulated by an expansionary monetary policy. The monetarists however recognize that extra monetary factors can under certain conditions be the origin of an increase in money supply.

For the structuralists, increasing price level is linked to the existence of intrinsic rigidities of the economic system in question. Inflation in this sense is caused by structural constraints and by non-monetary disequilibrium. According to the structuralist, neither monetary policy nor fiscal policy cause inflation; rather, it is caused by the economic structures of developing countries. Price mechanism functions in a framework of structures and these structures exist in imperfect markets. Thus, sectors like agriculture, international trade and the state are characterized by institutional rigidities that increase prices. This upward pressure of prices transforms into a general inflationary process through propagation mechanisms (Olivera, 1964; Argy, 1970).

The implication of this debate is diverse. For the monetarist, price stability is indispensable for the sustainability of economic growth. Monetary policy proposed by Friedman (1953) consists of a rule which fixes a growth rate of money in circulation marched it to the long-term growth rate of the GDP, follow it up. These eliminate the sources of major instability. The modern version of this argument is given by the theory of real economic cycles. Discretionary policy is associated to an inflationary bias if monetary authorities try to increase national product above its natural level. (Kydland and Prescott, 1977; Calvo, 1978; Barro and Gordon, 1983). For the structuralist, all restrictive monetary policy create unemployment and reduce economic growth in a country (Gilfason and Herbertsson, 2001). Since public and private savings are insufficient in the most part of the developing countries; the state must stimulate economic growth at the cost of budget deficit, which is financed by money creation and expansion of credit. Thus, permissive monetary policy seem to be necessary and inevitable (Mehra, 1991).

Empirical studies do not seem to differentiate between the two schools of thought. Some empirical literatures show that economic growth is inversely related to inflation (Judson and Orphanides, 1996; Andres, Domenech and Molinas, 1996). Most articles therefore underline a positive cost of inflation by introducing rational anticipation and flexible prices. Illustratively, inflation reduces the productivity of the two principal factors of production which are capital and wage and thus, reduce the return to capital (Varoudakis, 1995). Besides, liquidity constraints and/or high transaction cost hinder economic agents with low income to transfer their savings towards assets whose return are fixed on inflation (Kane and Moriset, 1993). These cost lead to the Friedman's rule which stipulates that monetary policy must generate a deflation such that the nominal interest rate will be zero and real interest rate will oppose inflation (Ragot, 2004). This theoretical recommendation contradicts the Central Bank's policy who knows that deflation is dangerous. Thus the Central Bank targets the levels of inflation between 1\% and $3 \%$ (Bemanke and Mishkin, 1997). A positive rate of inflation in the long-run is often attributed to the existence of nominal rigidities or errors of expectations (Akerlof, Dickens and Perry, 1996). A more heuristic manner, it is often said that a deflation creates problems related to credit and lead to solvable firm failures (Delong, 1999). Gylfason (1989) presents a negatively significant relationship between inflation and growth for 37 countries. Also, the endogenous growth models which exhibit a non trivial stationary economic growth remain very poor when monetary phenomenon. It shows the existence of a negative correlation between inflation rate and endogenous growth rate in the long-run, explained in a non causal manner (Taoufik and Villieu, 1993).

Tobin (1965) proposed a more complete formulation of the link between money growth and capital accumulation. According to Tobin, wealth takes two forms - capital and money - and the arbitrage between money and capital depends on the real return to each of the asset. If the real return rate to money depreciates with respect to that of capital, real wealth will tend to be composed of an increasing fraction of capital. An increase in capital accumulation boosts real growth. Money has a zero rate of nominal return. Thus, all monetary growth which provokes inflation even if well anticipated reduce the real return of cash with respect to capital, increase the real stock of capital and leaves real production at a stationary state (Lavigne and Villieu, 1996).

It suggests that monetary policy is not perfectly neutral and that it real impact is non-linear with respect to inflation rate (Bruno and Musso, 2000). The study by Litterman- Weiss (1985) as well as that of Geweke (1986) shows the neutrality of money on activity. The work of Christiano- Ljungqwist, (1988) however shows that money Granger causes output but fail to do so when estimation of the relationship is done using the first difference of money supply. According to Stock and Watson (1989), only the stochastic component of the growth rate of money supply influences activity.

The cost of inflation on economic growth in developing countries differs from the cost in developing countries. Using a non-linear regression on panel data, Burdekin and Ali (2004) showed that the marginal cost of inflation reduces when the 
general price level increases in developing countries. Fischer (1993) found lower negative coefficients of economic growth to the coefficients obtain for inflation rates lower than $15 \%$ for a sample composed of both develop and developing countries. Similar to Fisher's results, Ghost and Phillips (1998) found that a reduction of economic growth associated with an increase in inflation rate from $10 \%$ to $20 \%$ is lower than that observed when the rate of inflation increases from $40 \%$ to $50 \%$. In developing countries, a low rate of inflation $(3 \%$ ) has a positive significant effect on economic growth. Burdekin and Ali (2004) think that this results reflect the gains associated to the reject of deflation and not a positive effect associated to low rates of inflation. Thus, they insist on the consideration of the rate of inflation of $3 \%$ as that which would assure a durable economic growth in developing countries.

For many years now, studies have not been able to offer a clear empirical relationship between economic growth and inflation (Hwang, 2007). For example, during the periods of inflation and deflation, the economy of United States and a number of other states witnessed high and low growth rates. One of the first studies for 17 industrialized countries on the relationship between growth and inflation show that growth was positively correlated with low rates of inflation (below 8\%) between 1958 and 1967. However, during the same period on a sample of 7 developing countries, high rate of inflation (above 8\%) negatively influence growth (Thirwall and Barton, 1971). This result is not very different from that of Barro (1990) who had established that a inflation has a negative but low relationship with economic growth for the years 1970-1985 for a sample of 117 countries. But the same study also showed that a sustained and general increase in prices would reduce growth rate. Grimes (1991) succeeded in quantifying this effect. According to him, an increase in the rate of inflation for 0 to $9 \%$ reduces growth by a mean value of $1 \%$ per year. Following Gylfason (1991), economies that have high inflation rate, that is equal or greater that $20 \%$ per year grow relatively lower than others. According to Barro (1997) who used a data set comprising a sample of 100 countries for the period 1960-1999, an increase in a mean inflation rate of $10 \%$ per year reduce growth by $0,2 \%$ to $0,3 \%$ per year, everything being equal. Thus, an increase in the inflation rate of 5 to $50 \%$ per year will reduce economic growth by 1 to $1.5 \%$ per year. A robust statistical relationship between inflation and growth is generally established when a country experiment inflationary policies for a long period (Barro, 1997). It should be noted that ignorance about this threshold can induce a bad estimation of the cost of inflation on economic growth (Sarel, 1996).

\section{Methodology}

\subsection{The model}

The major objective of this article is to show the importance of monetary variables on economic growth in Cameroon. We assume that the Gross Domestic Product (GDP) is simultaneously determined by monetary factors and by real factors. Money in circulation is a function of the evolution of certain aggregates like the rate of growth of the GDP and public revenue. Inflation $(\mathrm{P})$ is a monetary phenomenon following the monetarist view point and the quantity theory of money. An increase of money (M) in circulation should increase the general price level. But, the increase of money in circulation can also boost economic activity. It is therefore established that a relationship between money, the general price level and the rate of growth of GDP can be represented by the relationship (1).

$$
\left\{\begin{array}{l}
P I B_{t}=f\left(M_{t}, P_{t}\right) \\
M_{t}=f\left(P I B_{t}, P_{t}\right) \\
P_{t}=f\left(M_{t}, P I B_{t}\right)
\end{array}\right.
$$

In the relation (1), exogenous variables can influence endogenous variables both at time $t$ and at time $t-i$, Relation (1) therefore specifies a VAR model which can be represented by the relation (2).

$$
\left\{\begin{array}{l}
P I B_{t}=\pi_{10}+\sum_{j=1}^{I} \pi_{1 j} P I B_{t-i}+\sum_{j=I+1}^{F} \pi_{1 i} M_{t-i}+\sum_{j=F+1}^{N} \pi_{1 j} P_{t-j}+e_{1 t} \\
M_{t}=\pi_{20}+\sum_{j=1}^{I} \pi_{2 j} P I B_{t-i}+\sum_{j=I+1}^{F} \pi_{2 j} M_{t-i}+\sum_{j i=F+1}^{N} \pi_{2 j} P_{t-i}+e_{2 t} \\
P_{t}=\pi_{30}+\sum_{j=1}^{I} \pi_{3 j} P I B_{t-i}+\sum_{j=I+1}^{F} \pi_{3 j} M_{t-i}+\sum_{j=F+1}^{N} \pi_{3 j} P_{t-i}+e_{3 t}
\end{array}\right.
$$

The system of equations (2) can be written in the following matrix form: 


$$
\left\{\left[\begin{array}{l}
P I B_{t} \\
M_{t} \\
P_{t}
\end{array}\right]=\left[\begin{array}{l}
\pi_{01} \\
\pi_{02} \\
\pi_{03}
\end{array}\right]+\left[\begin{array}{lll}
\pi_{11} & \pi_{12} & \pi_{13} \\
\pi_{21} & \pi_{22} & \pi_{23} \\
\pi_{31} & \pi_{32} & \pi_{33}
\end{array}\right]\left[\begin{array}{l}
P I B_{t-1} \\
M_{t-1} \\
P_{t-1}
\end{array}\right]+\left[\begin{array}{l}
e_{1 t} \\
e_{2 t} \\
e_{3 t}
\end{array}\right]\right.
$$

In relation (2), $i$ is the period, $n$ is the number of lags, $\pi_{1 j}$ are coefficients to be estimated and $e_{i t}$ the error term. An estimation of the relation (2) using the data of the Central Bank for the period 1960-2007 would enable us to make Granger causality test and most especially would enable us relate the effect of chocks of a variable on the others. Data used in this study come from the World Band. The period of study is 19602004.

\subsection{Stationnarity of variables}

It is necessary to test eventual co-integration between variables before estimating cross section data. The risk of estimating fallacious relationships and interpreting results faultily is high. To this effect, it is convenient to determine the order of integration. The general rule is that, co-integration is postulated if the series has the same order of integration. Thus, to determine the number of unit roots, we resort to the Augmented Dickey-fulley (ADF) test. Table 1 shows the result of the ADF test. All variables are integrated in the order 1 except for the general level of price variable which is integrated in the order 2.This implies that all the variables are not stationary but would become stationary after the first or second difference. So, we cannot claim any co-integration of variables from an ADF test only. A dynamic analysis of co-integration that would permit a deeper study of the question related to the co-integration of variables is therefore necessary.

$<$ Table 1 about here $>$

\subsection{Reducing the system of equations}

Before proceeding to the analysis of the system, it is convenient to determine the number of lag endogenous variables to include in the system. Thus, to formulate a VAR, the number of explanatory variables must be the same for each equation. So, the VAR model must be estimated many times from different number of explanatory variables and retain the system that present a better overall significance. For this, the contribution of each lag endogenous variables as well as that of each equation to the significance of the system would be optimal. Using a PcGive 12 software, we estimate several equations and realize from their different Fisher statistics that the best system of equation is the one that integrates two lag endogenous variables for each dependent variable. This is shown on table 2.

$<$ Table 2 about here $>$

\subsection{Dynamic analysis of co-integration}

A dynamic analysis of cointegration permits us to determine whether the variables of the system are integrated in the long-term. To this effect, it is based on the matrix of coefficient less an identity matrix. In an operational manner, this matrix notified as $\mathrm{P}_{0}$ of dimension $\left(\mathrm{n}^{\times} \mathrm{n}\right)$ is specified in the relation (4). $\mathrm{N}$ being the number of endogenous variables.

$$
P_{0}=\sum_{i=1}^{n} \pi_{i}-I_{n}
$$

If $\mathrm{P}_{0}=0$, the dynamics of the system is not influenced by the lagged endogenous values. This shows the importance of the rank (p) of the matrix (Note 1) $\mathrm{P}_{0}$. Thus, the rank of the matrix $\mathrm{P}_{0}$ determines the number of integrated linear combinations at level.

If the rang of the matrix $\mathrm{P}_{0}$ is equal to $n$ (the number of endogenous variables), all the variables of the system are integrated to the order zero. if $0<p<n, p$ relations of the system are integrated to the order zero. The general rule is that, co-integration is postulated if $0<p<n$. The matrix $P_{0}$ can be decomposed in two matrices - one called alpha which specify the effect of the coefficients of the lad variables on the dependent variable (memory effect), the other called beta which regroups the vector co-integrated or non co-integrated variables. The matrix $P_{0}$ which determines the evolution of the system in the long-term is given by the product of the two matrices (Johanson, 1998). A dynamic analysis of co-integration has enabled us to notice that two roots of the matrix $P_{0}$ are very small values. More so, the probability that the rank of the matrix. Thus the first two vectors of the matrix beta of annex 1 specify the vectors of co-integration. So, there are two linear combinations in the system (3). 
Since the roots of the matrix $\mathrm{P}_{0}$ greater than zero, there exists a long term relationship between the variables in the long-term. In other words, the variables of the system of equation (3) are co-integrated.

\section{Results}

The results of estimation are shown on table 3, 4 and 5. The model is significant since the value of $R^{2}$ is equal to 0,927 . Beyond, the diagnostic test does not indicate any econometric problem: errors are not correlated, the residual is normally distributed that to the transformations made, the variance of the residual are constant.

$<$ Table 3, 4, 5 and 5a about here $>$

One can observe that an increase in money supply can boost growth and that inflation is not a major determinant of economic growth. As a proof, an increase in the rate of inflation by $1 \%$ can provoke economic cycles which in the long-term would reduce growth by $0,025 \%$, see the graph (Note 2) A . An increase in money in circulation induces certain fluctuations that increase the rate of growth of the GDP by $1 \%$ to $2 \%$. Also, the results of our estimation show that an expansionary monetary policy does not necessarily lead to increase in the general price level in Cameroon. The economic cost of an anti-inflationary policy in terms of the production of goods and services is enormous. It should however be known that problems related to information asymmetry between banks and the promoters of projects causes credit rationing in most of the states in the Economic and Monetary Community of Central Africa (CEMAC). This can also reduce the growth rate below is optimal level.

$<$ Figure 1 about here $>$

In table 4, inflation is caused by economic growth (irrespective of the cause of this growth) and reduced with the general price level of the previous year. These two phenomenons were observed during the period of expansion. It is so because growth is often drawn by domestic demand in Cameroon. Take the example of the year 2008 growth is sustained by domestic demand with growth reaching the value $6.3 \%$ because household consumption was stimulated by increase in salaries and the number of people employed in the public sector. Gross investment also contributed to growth the same year because of the intensification of programs of infrastructure amelioration, the acquiring and renewal of tools of production in the electricity industry, water and manufacturing industries. We can also sight the beginning of the years 1980 and 2000 which were marked a massive entry of currency from and increase in the foreign demand of local products (MINFI, 2010).

$<$ Table 6 and 7 about here $>$

The Granger causality test presented on table 6 confirms the results. Thus, we can retain the following from this test : i) the money supply at time $t_{-2}$ causes growth at time $t$ causes growth in time $t$; ii) the growth at time $t_{-2}$ causes inflation at time $t$; iii) Inflation reduces the money in circulation. This last relation is established from literature: restrictive monetary policy is one of the appropriate solutions to fight inflation.

\section{Conclusion}

The objective of the article was to analyze the link between economic growth, inflation and money in circulation. A VAR model was constructed for data from Cameroon for the years 1960-2007 for the analysis. The results show that money in circulation causes growth and growth causes inflation. However, it was realised that an increase in money in circulation does not necessarily induce an increase in the general price level. Thus, it can be affirmed that monetary programming policy and most especially problems related to information asymmetry between banks and promoters of projects hinder the growth rate from reaching its optimal level in Cameroon.

\section{References}

Andres, J., Domenech, R., \& Molinas, C. (1996). Macroeconomic Performance and Convergence in OCDE Countries. European Economic Review, 40 (1), 1683-1704. doi:10.1016/S0014-2921(96)00014-1, http://dx.doi.org/10.1016/S0014-2921(96)00014-1

Akerlof, G., Dickens W., \& Perry, G. (1996). The Macroeconomics of Low Inflation. Brookings Paper on Economic Activity, 3(1), 1-59. doi:10.2307/2534646, http://dx.doi.org/10.2307/2534646

Argy, V. (1970). Structural inflation in developing countries. Oxford, Economics Papers, Vol.22, PP.73-85.

BAD (2002). Cameroun : Programme d'ajustement structurel II (PASII), Rapport d'évaluation de performance de projet (REPP), Département de l'évaluation des opérations, [Online], available: http://www.afdb.org/fileadmin/uploads/afdb/Documents/Evaluation-Reports/19614240-FR-CAMEROON-PAS-III.PDF 
Barro, R., and Gordon, D. (1983). Rules, discretion and reputation in a model of monetary policy. Journal of Monetary Economy, 91(4), PP 589-610.

Barro, R. (1990). Comment on Dornbusch, F., Sturzenegger, H., Wolf "Extreme inflation: Dynamics and stabilization". Brooking Papers on Economic Activity, 2 (1), 68-75

Barro, R. (1991). Economic growth in a cross section of countries. Quarterly Journal of Economics, 106, 404-443. doi:10.2307/2937943, http://dx.doi.org/10.2307/2937943

Barro, R. (1995). Inflation and economic growth. Bank of England Quarterly Bulletin, 1064-176.

Barro, R. (1997). Determinants of economic growth: a cross country empirical study. MIT Press, Cambridge MA London, UK

Bernanke, B., and Mishkin, F. (1997). Inflation targeting: A New Framework for Monetary Policy? The Journal of Economic Perspectives, 11(2), 97-116.

Bruno, M. (1978). Exchange rates, impact costs, and wage price dynamics. Journal of Political Economy, 86 (3), 379-403. doi:10.1086/260678, http://dx.doi.org/10.1086/260678

Bruno, O., and Musso, P.( 2000). Volatilité de l'inflation et croissance économique. Revue Economique, 51( 3), 693-701.

Burdekin, R., Denzau, A., Keil, M., Sitthiyot, T., and Willett, T. (2004). When does inflation hurt economic growth?

Different nonlinearities for different economies. Journal of Macroeconomics, 26 (2), 519-532.

doi:10.1016/j.jmacro.2003.03.005, http://dx.doi.org/10.1016/j.jmacro.2003.03.005

Calvo, G. (1978). On the time-consistency of optimal policy in monetary economy. Econometrica, 46 (6), 1411-1428. doi:10.2307/1913836, http://dx.doi.org/10.2307/1913836

Chrsitiano, L., and Ljunggvist, L. (1988). Money does Granger-Cause Output in the Bivariate Money-Output Relation.

Journal of Monetary Economics, .22 (3), 217-235. doi:10.1016/0304-3932(88)90020-7, http://dx.doi.org/10.1016/0304-3932(88)90020-7

Cozier, B., and Jack S. (1992). Inflation and Macroeconomic Performance: Some Cross-Country Evidence. Working Paper 92- 6, Department of Monetary and Financial Analysis, Bank of Canada

Delong, B. (1999). Should we fear deflation. Brookings Paper on Economic Activity, 1(1) 23-45.

Fischer, S. (1993). The role of macroeconomic factors in growth. Journal of Monetary Economics, .32 (2), 485-512. doi:10.1016/0304-3932(93)90027-D, http://dx.doi.org/10.1016/0304-3932(93)90027-D

Feldstein, M. (1996). The Costs and Benefits of Going from Low Inflation to Price Stability. NBER Working Paper 5469

Fischer, S. (1993). The Role of Macroeconomic Factors in Growth. NBER Working Paper 4565.

De Gregorior, J., and Guidotti, P. (1995). Financial development and economic growth. World Development, 23(1), 433-448. doi:10.1016/0305-750X(94)00132-I, http://dx.doi.org/10.1016/0305-750X(94)00132-I

FMI (2008). L'économie mondiale au service de tous, Rapport annuel 2008, [Online], available : http://www.imf.org/external/french/pubs/ft/ar/2008/pdf/ar08_fra.pdf

Friedman, M. (1953). Essay in positive economics, Chicago

Friedman, M. (1960). A program for monetary stability. [Online], available : New York: Fordham University Press http://www.questia.com/PM.qst?a $=o \& d=22831717$

Geweke, J. (1986). The Super neutrality of Money in the United States: an Interpretation of the Evidences. Econometrica, 54(1), 1-21. doi:10.2307/1914154, http://dx.doi.org/10.2307/1914154

Ghosh, A., and Phillips, S. (1998). Warning: Inflation may be harmful to your growth. International Monetary Fund Staff Papers, 45(1), 672-710. doi:10.2307/3867589, http://dx.doi.org/10.2307/3867589

Gordon, R. (1988). The role of wages in the inflation process. American Economic Review, 1.78 (2), 276-283.

Grimes, A. (1991). The effects of inflation on growth: some international evidence. Weltwirtschaftliches Archive, 78(2), 276-283.

Gylfason, T. (1989). Inflation, Growth, and External Debt: A View of the Landscape. World Economy, Vol 127(4), 631-644.

Gylfason, T. (1991). Inflation, Growth, and External Debt: A View of the Landscape. University of Iceland, Mimeo, 
Gilfason, T., and Herbertsson, T. (2001). Does inflation matters for growth. Japan and World Economy, 13 (1), 405-428.

Hwang,Y. ( 2007). Causality between inflation and real growth. Economics Letters, 94 (3), 146-153. doi:10.1016/j.econlet.2006.09.010, http://dx.doi.org/10.1016/j.econlet.2006.09.010

Ho-Chuan Huang, Shu-Chin Lin , and Dong-Hyeon Kim, Chih-Chuan Yeh (2010). Inflation and the finance growth nexus. Economic Modelling, 27(3), 229-236. doi:10.1016/j.econmod.2009.09.003, http://dx.doi.org/10.1016/j.econmod.2009.09.003

Howitt, P. (1990). Zero Inflation as a Long-Term Target for Monetary,Policy. In Zero Inflation: The Goal of Price Stability, ed. Richard G. Lipsey, Policy Study 8. Toronto, Canada: C.D. Howe Institute.

Johansen, S. (1988). Statistical analysis of cointegration vectors. Journal of Economic Dynamics and Control, 12 (2), 2316254. doi:10.1016/0165-1889(88)90041-3, http://dx.doi.org/10.1016/0165-1889(88)90041-3

Judson, R., and Orphanides, A. (1996). Inflation, Volatility and Growth. Mimeo Board of Governors of the Federal Reserve System.

Kane C., and Moriset, J. (1993). Who Would Vote for Inflation in Brazil ? Policy Research Working Paper, No. 1183, The World Bank.

Klomp,J., and Haan, J. (2009). Political institutions and economic volatility. European Journal of Political Economy, 25 (2009), 311-326. doi:10.1016/j.ejpoleco.2009.02.006, http://dx.doi.org/10.1016/j.ejpoleco.2009.02.006

Kydland, F., and Prescott, E. (1977). Rules rather than discretion: the inconsistency of optimal plans. Journal of Political Economy, 85 (3), 473-493. doi:10.1086/260580, http://dx.doi.org/10.1086/260580

Levine, R., and Renelt, D. (1992). A Sensitivity Analysis of Cross- Country Growth Regressions. American Economic Review 25 (2), 173-193.

Lavigne, A., and Villieu, P. (1996). Actualités des politiques monétaires et financiers. Revue Economie Politique, 106 (4), 492-568.

Levine, R., and Sara, J. Z. (1993). What We Have Learned About Policy and Growth from Cross-Country Regressions? American Economic Review, 83, PP 426-430, [Online], available: http://www.development.wne.uw.edu.pl/uploads/ development.wne.uw.edu.pl/uploads/Courses/dev_ross_zervos.pdf

Litterman, R., and Weiss, L. (1985). Money, Real Interest Rate and Output: A Reinterpre- tation of Postwar US Data. Econometrica, 53 (2), 189-256.

Olivera, J. (1964). Structural inflation and Latin American structuralism. Oxford Economics Papers, Vol. 16, PP. 321-332.

Mamalepot, J. (2004). La politique monétaire en Afrique Centrale, Journée du cercle des étudiants du programme de troisième cycle inter universitaire, Yaoundé.

McKinnon, R. (1973). Money and Capital in Economic Development, Brookings Institute, Washington.

Mehra, Y. (1991). Wage growth and the inflation process: an empirical note. American Economic Review, 81(2), 931-937.

MINEPAT (2009). Document de Stratégie pour la Croissance et l'Emploi, Yaoundé, [Online], available: http://www.google.cm/url?q=http://www.legicam.org/index.php\%3Foption\%3Dcom_docman\%26task\%3Ddoc_downlo ad\%26gid\%3D223\%26Itemid\%3D\&sa=U\&ei=FGM8TcfZA46u8QP3jImgCA\&ved=0CAsQFjAA\&usg=AFQjCNEc3B qIc11PNSuqVJXAikytxqAL8g

MINFI (2009). Loi des finances 2010 : Rapport sur la situation et les perspectives économiques, sociales et financière de la nation, exercice 2009, Yaoundé, [Online], available:

http://www.performance-publique.gouv.fr/fileadmin/medias/documents/ressources/PLF2010/REF10_1.pdf

Motley, B. (1994). Growth and inflation: a cross country study, CEPR, Federal Reserve Bank of San Francisco, Stanford, CA, [online], available: http://ideas.repec.org/a/fip/fedfer/y1998p15-28n1.html

Mundell, R. A. (1963). Inflation and Real Interest. Journal of Political Economy, 71, 280-300. doi:10.1086/258771, http://dx.doi.org/10.1086/258771

Ragot, X. (2004). Une théorie de l'inflation optimale fondée sur les contraintes de crédit. Revue Economique, 55( 3), 469-478. 
Saini, K. (1982). The monetarist explanation of inflation: the experience of six Asian countries. World Development, 10 (3), 871-884. doi:10.1016/0305-750X(82)90062-6, http://dx.doi.org/10.1016/0305-750X(82)90062-6

Sarel, M. (1996). Nonlinear effects of inflation on economic growth. International Monetary Fund Staff Papers, 43(2), 199-215. doi:10.2307/3867357, http://dx.doi.org/10.2307/3867357

Shaw, E. (1973), Financial Deepening in Economic Development, Oxford University Press, New York.

Stock J., and Watson, M. (1989). Interpreting the Evidence on Money Income Causality. Journal of Econometrics, 161-182. doi:10.1016/0304-4076(89)90035-3, http://dx.doi.org/10.1016/0304-4076(89)90035-3

Taoufik, R., and Villieu, P. (1993). Accélération monétaire et croissance endogène. Revue Economique, 44( 2), 257-285

Taylor, J. (1996). Stabilisation policy and long-term economic growth. in Landau, R., Taylor, T., Wright, G., (ed), The Mosaic of Economic Growth, Stanford University Press, Stanford CA, 129-149.

Thirlwall, A., and Barton, C. (1971). Inflation and Growth: the international evidence. Banca Nazionale del Lavoro Quarterly Review, 98 (2), 263-275.

Tobin, J. (1965). Money and Economic Growth. Econometrica, 33 (4), 671- 684. doi:10.2307/1910352, http://dx.doi.org/10.2307/1910352

Varoudakis, A. (1995). Inflation, inégalités de répartition et croissance. Revue économique, 46( 3), 889-899.

\section{Notes}

Note 1. See equation (4)

Note 2. The graph presents the effects of the increase in a variable on another variable. The graph No. 2 presents the effect of inflation on economic growth.

Table 1. The order of integration of the series

\begin{tabular}{|l|c|c|c|}
\hline \multicolumn{1}{|c|}{ Variable } & Statistics Adf & Number of unit roots & Level of significance (\%) \\
\hline GDP & $-9.076^{* *}$ & 1 & 1 \\
\hline Money supply & $-10.03 * *$ & 1 & 1 \\
\hline The general price level & $-6.996^{* *}$ & 2 & 5 \\
\hline
\end{tabular}

Source: Estimated from the Central Bank data

Table 2. Significance of endogenous variables as well as that of the equations of the system

\begin{tabular}{|ll|llll|}
\hline \multicolumn{2}{|c|}{$\begin{array}{c}\text { Test of significance of each } \\
\text { lag endogenous variables }\end{array}$} & \multicolumn{3}{|c|}{$\begin{array}{c}\text { Test of the overall significance of } \\
\text { endogenous variables lagged once or twice. }\end{array}$} \\
\hline Lag 2 & $\mathrm{~F}(9,75)=5.2228[0.0000]^{* *}$ & Lag $2-2$ & $\mathrm{~F}(9,75)=5.2228[0.0000]^{* *}$ & -15.3646 & -14.8580 \\
\hline $\operatorname{Lag} 1$ & $\mathrm{~F}(9,75)=12.186[0.0000]^{* *}$ & $\mathrm{Lag} 1-2 \mathrm{~F}(18,88)$ & $=7.5003[0.0000]^{* *}-14.3646$ & -14.2379 \\
\hline
\end{tabular}

Source : We estimate from Central Bank data 
Table 3. Growth equation

\begin{tabular}{|c|c|c|c|c|}
\hline Variables & Coefficient & Standard Deviation & t-statistics & t-prob \\
\hline GDP_1 & -0.562794 & 0.2236 & -2.52 & 0.0169 \\
\hline GDP_2 & -0.623444 & 0.1968 & -3.17 & 0.0033 \\
\hline inflation_1 & 6.26563 & 16.60 & 0.378 & 0.7082 \\
\hline inflation_2 & -6.38359 & 14.68 & -0.435 & 0.6666 \\
\hline Money_1 & 0.094700 & 0.07659 & 1.24 & 0.2250 \\
\hline Money_2 & 0.121985 & 0.07196 & 1.70 & 0.0994 \\
\hline Constant & -0.000242 & 0.009640 & -0.0251 & 0.9801 \\
\hline sigma =0.0609582 RSS $=0.1226247215$ \\
\hline
\end{tabular}

Table 4. Inflation equation

\begin{tabular}{|c|c|c|c|c|}
\hline Variables & Coefficient & Standard Deviation & t-statistics & t-prob \\
\hline GDP_1 & 0.00271096 & 0.002926 & 0.926 & 0.3609 \\
\hline GDP_2 & 0.00508961 & 0.002574 & 1.98 & 0.0564 \\
\hline inflation_1 & -0.921734 & 0.2171 & -4.24 & 0.0002 \\
\hline inflation_2 & -0.324169 & 0.1921 & -1.69 & 0.1010 \\
\hline Money_1 & -0.000976480 & 0.001002 & -0.974 & 0.3369 \\
\hline Money_2 & -0.00152455 & 0.0009415 & -1.62 & 0.1149 \\
\hline Constant & $1.12136 \mathrm{e}-005$ & 0.0001261 & 0.0889 & 0.9297 \\
\hline sigma =0.000797595 RSS $=2.099318561$ e-005 \\
\hline
\end{tabular}

Table 5. Money supply equation

\begin{tabular}{|c|c|c|c|c|}
\hline Variables & Coefficient & Standard Deviation & t-statistics & t-prob \\
\hline GDP_1 & 0.471092 & 0.4181 & 1.13 & 0.2680 \\
\hline GDP_2 & 0.0291636 & 0.3678 & 0.0793 & 0.9373 \\
\hline inflation_1 & 65.0365 & 31.03 & 2.10 & 0.0438 \\
\hline inflation_2 & 31.8444 & 27.45 & 1.16 & 0.2544 \\
\hline Money_1 & -0.8052 & 0.1432 & -5.62 & 0.0000 \\
\hline Money_2 & -0.5350 & 0.1345 & -3.98 & 0.0004 \\
\hline Constant & -0.0025 & 0.01802 & -0.118 & 0.9068 \\
\hline sigma $=0.113964 \quad \mathrm{RSS}=0.4286001567$ \\
\hline
\end{tabular}

$\log$-likelihood 342.828, $\quad-\mathrm{T} / 2 \log \mid$ Omega| $\quad$ 513.1; $\mathrm{R}^{\wedge} 2(\mathrm{LR}): 0.927691 \quad \mathrm{R}^{\wedge} 2(\mathrm{LM}): 0.634$

Number of observations: 40; number of parameters: 21

Source: Estimated using central bank data 
Table 5a. Diagnostic test

\begin{tabular}{|c|c|}
\hline Vector Portmanteau ( 5 & \\
\hline $\begin{array}{l}\text { Vector AR } 1-2 \text { test: } \\
0.91181[0.5671]\end{array}$ & $\mathrm{F}(18,71)=$ \\
\hline $\begin{array}{l}\text { Vector Normality test: } \\
{[0.1498]}\end{array}$ & $\mathrm{Chi}^{\wedge} 2(6)=9.4495$ \\
\hline $\begin{array}{l}\text { Vector Hetero test: } \\
0.91316[0.6533]\end{array}$ & $\mathrm{F}(72,87)=$ \\
\hline $\begin{array}{l}\text { Vector Hetero-X test: } \\
{[0.9915]}\end{array}$ & $\mathrm{F}(162,8)=0.37236$ \\
\hline
\end{tabular}

Source: Estimates from central bank data

Table 6. Granger test

\begin{tabular}{|c|c|}
\hline Y cause $X$ (the first variable causes the second) & Y cause $X$ (the first variable causes the second) \\
\hline inflation_1@GDP Chi^2(1)=0.14253 [0.7058] & Money_1@inflation Chi^2(1)=0.94953 [0.3298] \\
\hline inflation c_2@GDP Chi^2(1)=0.18900 [0.6637] & Money_2@inflation Chi^2(1)=2.6221 [0.1054] \\
\hline Money_1@GDP Chi^2(1)=1.5289[0.2163] & GDP_1@Money Chi^2(1)=1.2695 [0.2599] \\
\hline Money_2@GDP Chi^2(1)=2.8739[0.0900] & GDP_2@Money Chi^2(1)=0.0062857 [0.9368] \\
\hline GDP_1@inflation $\mathrm{Chi}^{\wedge} 2(1)=0.85833[0.3542]$ & inflation_1@MoneyChi^2(1) $4.3937[0.0361]^{*}$ \\
\hline GDP_2@inflation $\mathrm{Chi}^{\wedge} 2(1)=3.9085[0.0480]^{*}$ & inflation_2@Money Chi^2(1)=1.3456 [0.2460] \\
\hline
\end{tabular}

Source : Estimate from data

Table 7. Eigen Values and rang of the matrix $\mathrm{P}_{0}$

\begin{tabular}{|c|c|c|c|c|}
\hline \multicolumn{2}{|c|}{ Eigen values } & \multicolumn{3}{|c|}{ Rang of the matrix $P_{0}$} \\
\hline Eigen value & loglik for rank & $\mathrm{H}_{0}$ :rank & $<=$ Trace test & [ Prob] \\
\hline & 354.1667 & 0 & 37.640 & {$[0.005] * *$} \\
\hline 0.41045 & 364.9988 & 1 & 15.976 & $15.976[0.041] *$ \\
\hline 0.27878 & 371.6985 & 2 & 2.5769 & $2.5769[0.108]$ \\
\hline 0.060918 & 372.9870 & & & \\
\hline
\end{tabular}

Source: Estimates from the Central Bank data 
Table 8. I(1) cointegration analsis, 1960 to 2007.

Source: Estimates from the Central Bank data

\begin{tabular}{|c|c|c|c|}
\hline \multicolumn{4}{|c|}{ Beta matrix } \\
\hline GDP & 1.0000 & -0.0015 & 5.1121 \\
\hline Inflation & 73.697 & 1.0000 & 280.05 \\
\hline Money & -0.6248 & 0.0004 & 1.0000 \\
\hline \multicolumn{4}{|c|}{ Alpha matrix } \\
\hline GDP & -0.673 & 121.88 & -0.25841 \\
\hline Inflation & 0.0026 & -2.506 & 0.00024 \\
\hline Money & 2.9828 & 12.018 & -0.48192 \\
\hline \multicolumn{4}{|c|}{$P_{0}$ matrix } \\
\hline & GDP & Inflation & Money \\
\hline GDP & -2.1862 & -0.11795 & 0.2166 \\
\hline Inflation & 0.0078 & -2.2459 & -0.0025 \\
\hline Money & 0.50026 & 96.881 & -2.3402 \\
\hline
\end{tabular}
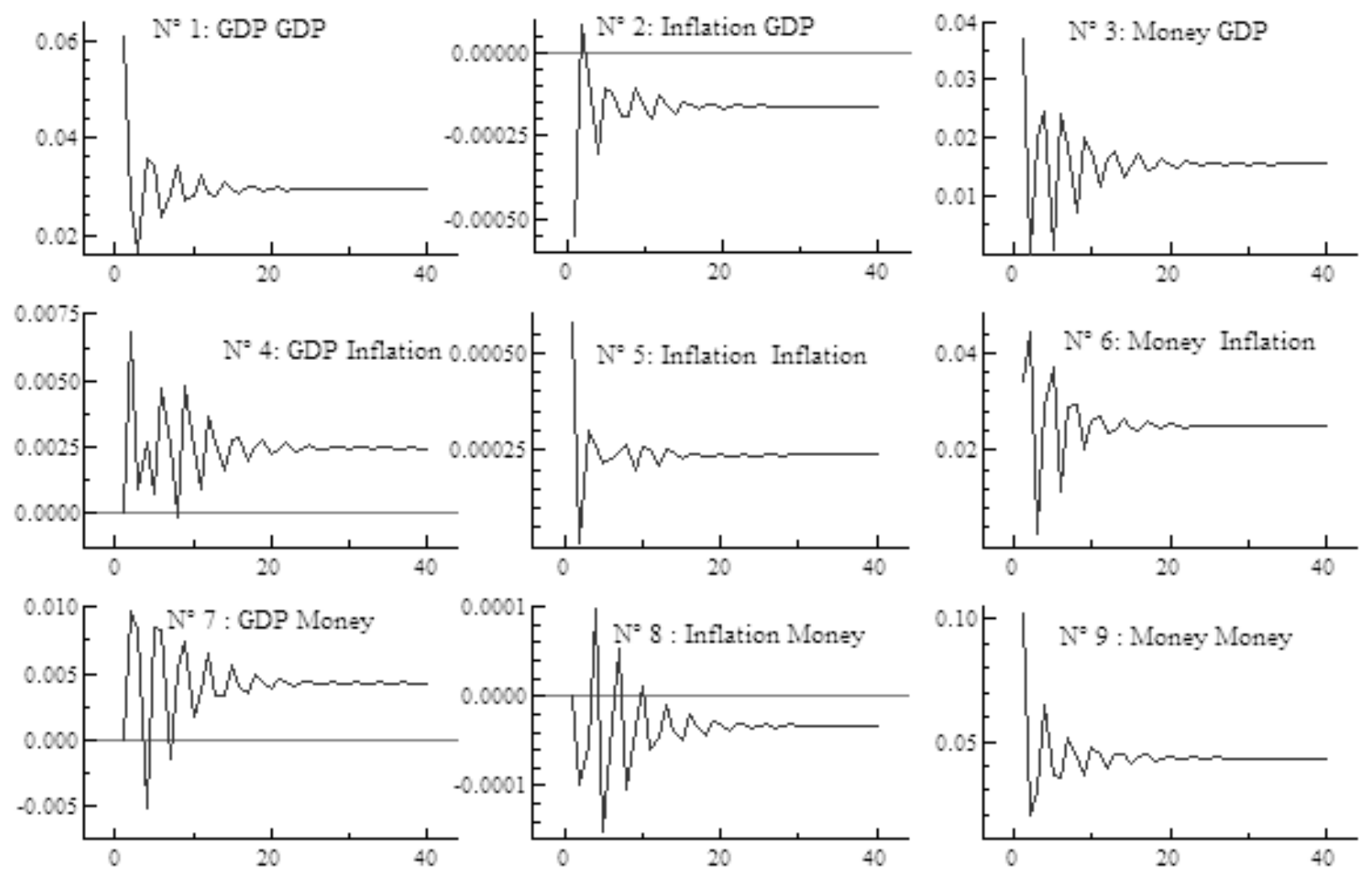

Figure 1. The effects of lagged endogenous variables on the dependent variables Source: Estimated from the Central Bank data 